Case Report

\title{
Pulmonary Embolism as the First Manifestation of Multiple Myeloma
}

\author{
N. Vallianou, V. Lazarou, J. Tzangarakis, R. Barounis, and E. Sioula \\ Internal Medicine Department, Evangelismos General Hospital, 45-47 Ipsilantou Street, 10676 Athens, Greece \\ Correspondence should be addressed to N. Vallianou; natalia.vallianou@hotmail.com
}

Received 21 May 2013; Accepted 26 August 2013

Academic Editor: Werner Rabitsch

Copyright (C) 2013 N. Vallianou et al. This is an open access article distributed under the Creative Commons Attribution License, which permits unrestricted use, distribution, and reproduction in any medium, provided the original work is properly cited.

\begin{abstract}
Multiple myeloma is considered a hypercoagulable state due to several mechanisms such as the increased IL-6 and immunoglobulins production, the defective fibrinolytic mechanism, and the acquired resistance to activated protein $\mathrm{C}$ that are involved in the pathogenesis and clinical futures of the disease. We describe a case of a female patient who presented to the hospital with pulmonary embolism as the first manifestation of the hypercoagulability of multiple myeloma.
\end{abstract}

\section{Introduction}

Venous thromboembolic disease has been well established as a major complication of myeloma therapy [1-3]. Also, thrombosis is recognized as the most frequent complication of malignant diseases. Patients with multiple myeloma are predisposed to an increased incidence of venous thromboembolic disease and often have additional risk factors from prolonged bed rest, back pain, and the presence of amyloidosis and hyperviscosity, all of which contribute to hypercoagulability [4]. Herein, we describe the case of a patient who presented with pulmonary embolism and was subsequently found to have multiple myeloma.

\section{Case Presentation}

A forty-two-year-old female patient came to the hospital due to dyspnea and swelling of her left leg, which had started two days before her admission.

On physical examination, she had tachypnea and tachycardia, while she had crackles on auscultation of the thorax. Her left leg was edematous from the hip down to the ankle. A triplex of the venous vasculature of the left leg revealed thrombosis of the left femoral venous, while the vasculature of the right leg was normal. Due to tachypnea with hypoxia, she underwent a spiral thoracic CT scan that confirmed the diagnosis of pulmonary embolism.
The ECG showed sinus tachycardia. From the laboratory tests, she had a very high ESR $(120 \mathrm{~mm} / \mathrm{h})$, an albumin to globulins ration of 0.86 , serum albumin: $2.7 \mathrm{~g} / \mathrm{dL}$, $\beta 2$-microglobulin: $2,076 \mu \mathrm{g} / \mathrm{L}$, while IgG measurement was $4,490 \mathrm{mg} / \mathrm{dL}$, IgM was $36.9 \mathrm{mg} / \mathrm{dL}$, IgA was $40.5 \mathrm{mg} / \mathrm{dL}$, and there was a band formed in the place of gamma globulins in serum electrophoresis. Because of those laboratory values, she underwent a bone marrow aspiration, which confirmed the presence of $70 \%$ myeloma cells in the bone marrow. Thrombophilia laboratory tests were normal. The patient was initially placed on low-molecular-weight heparin (LMWH) and afterwards on warfarin for six months. After having been hospitalized for pulmonary embolism for 15 days, she started therapy with bortezomib and she remains well until today.

\section{Discussion}

Several different mechanisms have been described as possible causative factors for venous thromboembolic disease in patients with multiple myeloma. High levels of IL-6 are associated with the coagulation cascade activity [5]. The presence of abnormal levels of immunoglobulins alters the network structure of gels formed from purified fibrinogen. The fibrin fibers that compose these gels have been shown by electron microscopy to be much thinner than normal. Moreover, plasma clots comprising thin, small-diameter fibrin fibers are found to be relatively resistant to plasmin degradation 
$[6,7]$. Also, acquired activated protein $\mathrm{C}$ resistance (APC-R) was recognized to be common in patients with cancer and recently especially among patients with multiple myeloma [2, 8-10]. Multiple myeloma patients also have decreased fibrinolytic activity because of increased PAI-1 (plasminogen activator inhibitor-1) activity, which is positively related to elevated IL-6 levels [11]. Apart from having an increased risk of pulmonary embolism due to immunomodifying agents that are included in multiple myeloma therapy, patients with newly diagnosed multiple myeloma, that is prior to having received therapy, seem to be at increased risk for venous thromboembolic disease and pulmonary embolism [12]. Our patient presented to the hospital with pulmonary embolism and she was diagnosed as having multiple myeloma, stage II according to the ISS. Thrombophilia tests were normal, that is, testing for antithrombin III, protein $\mathrm{C}$, protein $\mathrm{S}$, lupus anticoagulant-1, while the molecular testing for FV Leiden, prothrombin gene, and MTHFR were negative too. The hypercoagulability associated with multiple myeloma, which is explained by the above-mentioned mechanisms, could have been responsible for her presentation with pulmonary embolism. Further studies are needed to access the risk for pulmonary embolism in multiple myeloma patients prior to the administration of immunomodifying agents and/or chemotherapy.

\section{References}

[1] V. H. Jiménez-Zepeda and V. J. Domínguez-Martínez, "Acquired activated protein $\mathrm{C}$ resistance and thrombosis in multiple myeloma patients," Thrombosis Journal, vol. 4, article 11, 2006.

[2] F. Elice, L. Fink, G. Tricot, B. Barlogie, and M. Zangari, "Acquired resistance to activated protein C (aAPCR) in multiple myeloma is a transitory abnormality associated with an increased risk of venous thromboembolism," British Journal of Haematology, vol. 134, no. 4, pp. 399-405, 2006.

[3] G. Srkalovic, M. G. Cameron, S. R. Deitcher, K. KattkeMarchant, and M. A. Hussein, "Incidence and risk factors of venous thromboembolism (VTD) in patients with amyloidosis," International Seminars in Surgical Oncology, vol. 2, article 17, 2005.

[4] G. Srkalovic, M. G. Cameron, L. Rybicki, S. R. Deitcher, K. Kattke-Marchant, and M. A. Hussein, "Monoclonal gammopathy of undetermined significance and multiple myeloma are associated with an increased incidence of venothromboembolic disease," Cancer, vol. 101, no. 3, pp. 558-566, 2004.

[5] D. A. Gabriel, L. A. Smith, and J. D. Folds, "The influence of immunoglobulin (IgG) on the assembly of fibrin gels," Journal of Laboratory and Clinical Medicine, vol. 101, no. 4, pp. 545-552, 1983.

[6] H. Lackner, V. Hunt, M. B. Zucker, and J. Pearson, "Abnormal fibrin ultrastructure, polymerization, and clot retraction in multiple myeloma," British Journal of Haematology, vol. 18, no. 6, pp. 625-636, 1970.

[7] M. E. Carr Jr., R. M. Dent, and S. L. Carr, "Abnormal fibrin structure and inhibition of fibrinolysis in patients with multiple myeloma," Journal of Laboratory and Clinical Medicine, vol. 128, no. 1, pp. 83-88, 1996.

[8] N. Haim, N. Lanir, R. Hoffman, A. Haim, M. Tsalik, and B. Brenner, "Acquired activated protein $\mathrm{C}$ resistance is common in cancer patients and is associated with venous thromboembolism," American Journal of Medicine, vol. 110, no. 2, pp. 91-96, 2001.

[9] M. Zangari, F. Saghafifar, P. Mehta, B. Barlogie, L. Fink, and G. Tricot, "The blood coagulation mechanism in multiple myeloma," Seminars in Thrombosis and Hemostasis, vol. 29, no. 3, pp. 275-281, 2003.

[10] G. P. Talamo, S. Ibrahim, D. Claxton, G. J. Tricot, L. M. Fink, and M. Zangari, "Hypercoagulable states in patients with multiple myeloma can affect the thalidomide-associated venous thromboembolism," Blood Coagulation and Fibrinolysis, vol. 20, no. 5, pp. 337-339, 2009.

[11] M. Yağci, G. T. Sucak, and R. Haznedar, "Fibrinolytic activity in multiple myeloma," American Journal of Hematology, vol. 74, no. 4, pp. 231-237, 2003.

[12] J. J. A. Auwerda, P. Sonneveld, M. P. M. De Maat, and F. W. G. Leebeek, "Prothrombotic coagulation abnormalities in patients with newly diagnosed multiple myeloma," Haematologica, vol. 92, no. 2, pp. 279-280, 2007. 


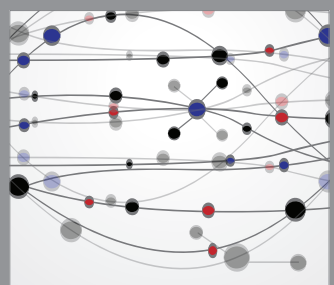

The Scientific World Journal
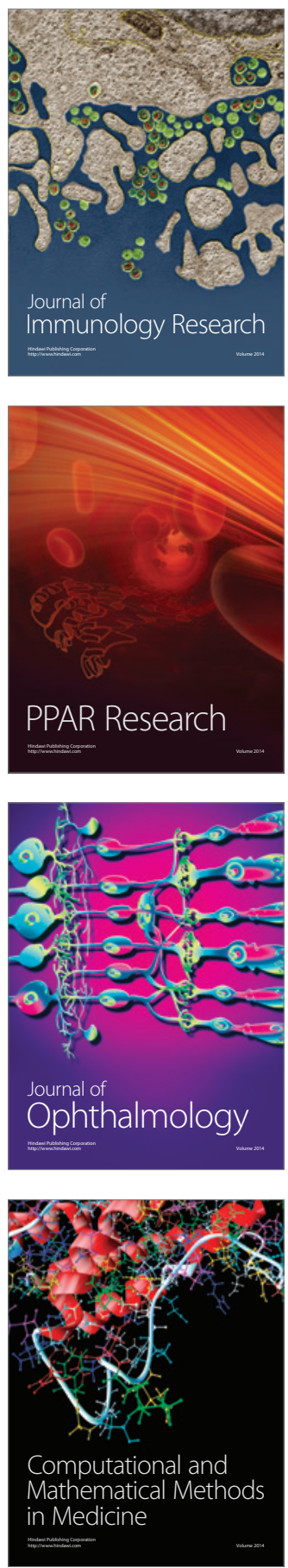

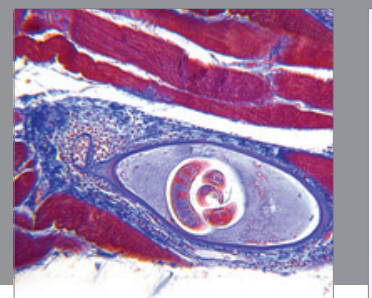

Gastroenterology

Research and Practice
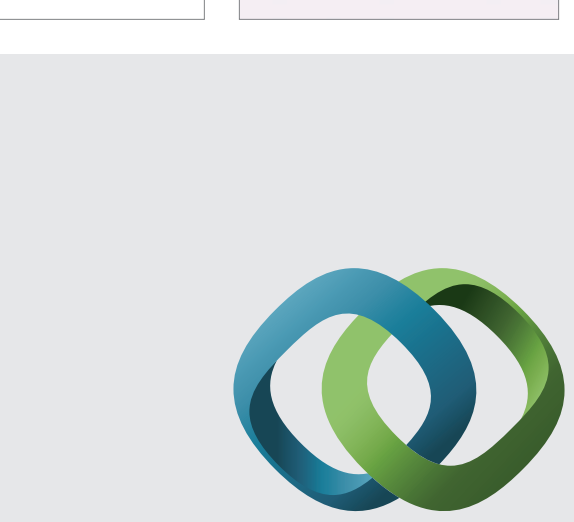

\section{Hindawi}

Submit your manuscripts at

http://www.hindawi.com
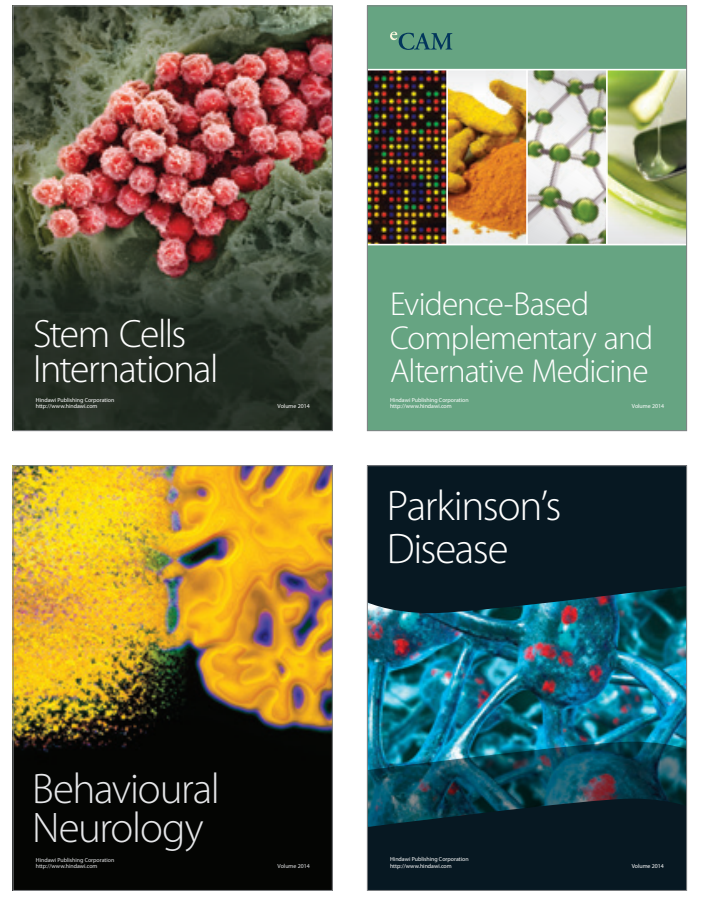
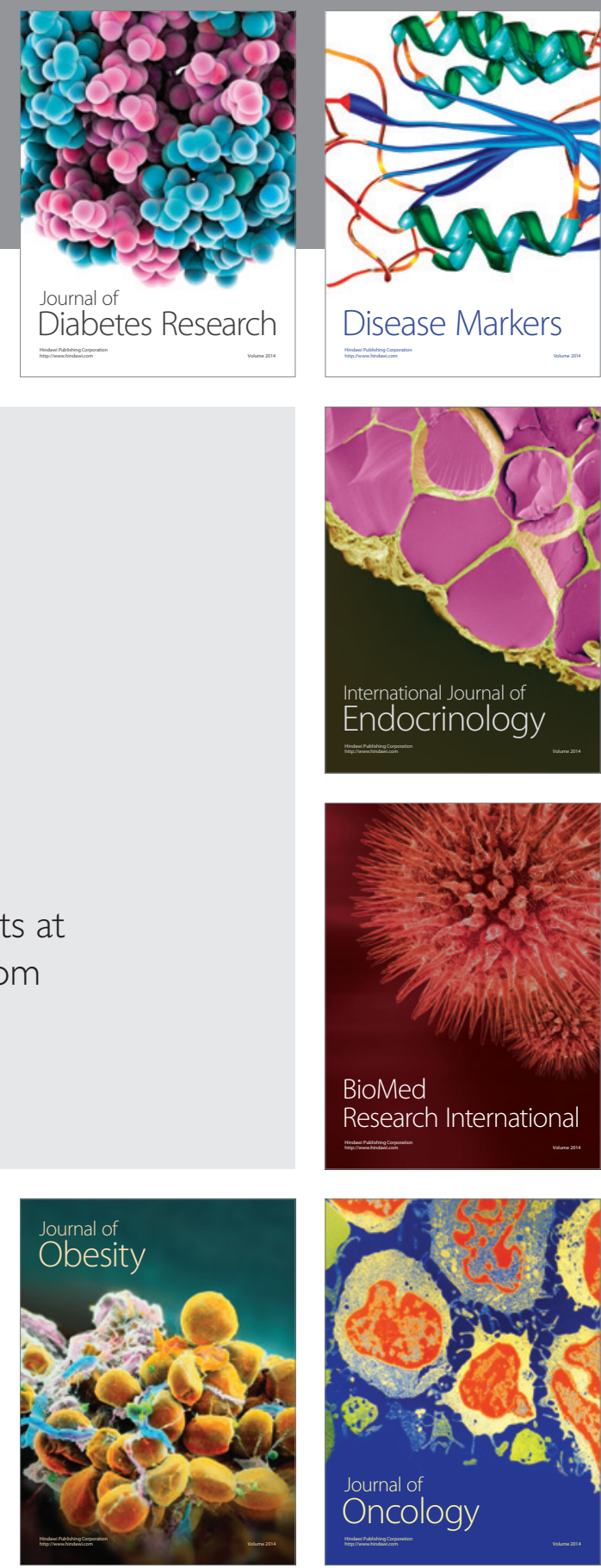

Disease Markers
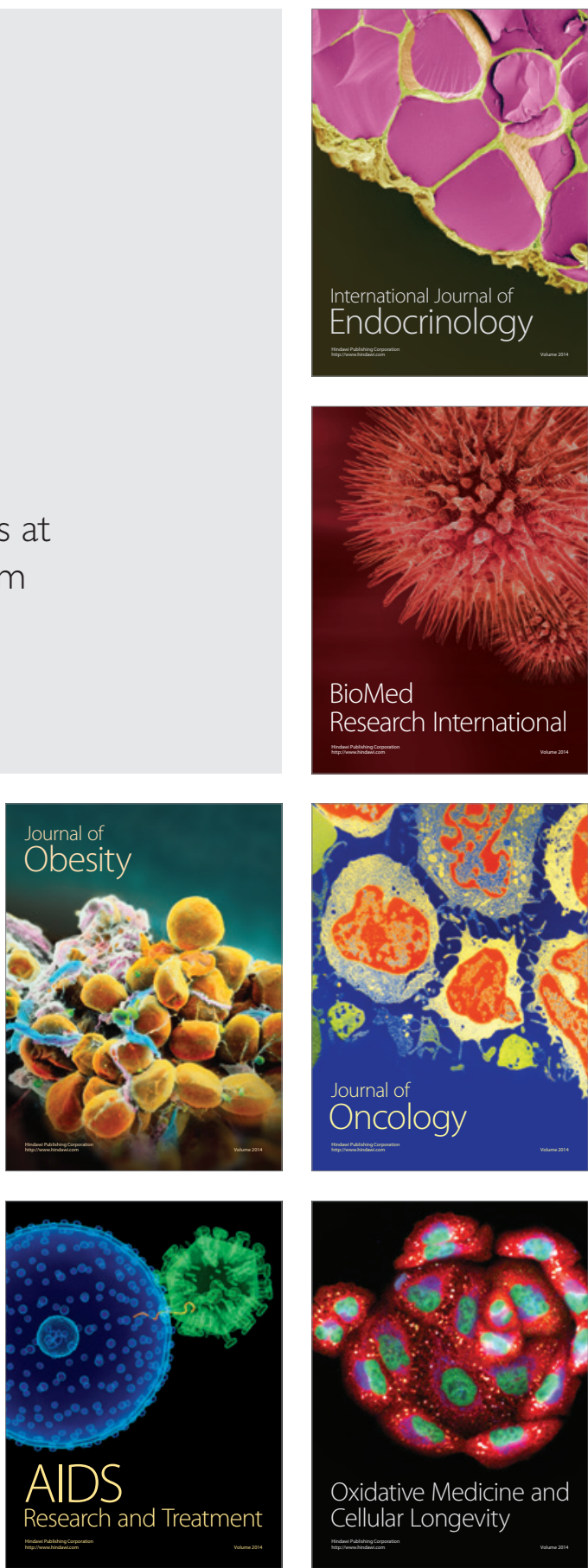